\title{
souna of Molecular Virology and Immunology
}

\author{
mRNA Temelli Aşıların İn-vivo Illetimi ve Uygulama Yolları \\ In-vivo Delivery of mRNA-Based Vaccines and Administration Routes
}

\begin{abstract}
Ramazan GÜMRAL ${ }^{1}[$ ID $]$
${ }^{1}$ Sağlık Bilimleri Üniversitesi, Gülhane Tıp Fakültesi, Tıbbi Mikrobiyoloji Anabilim Dalı, Ankara, Türkiye [Department of Medical Microbiology, Gulhane Medical Faculty, University of Health Sciences, Ankara, Turkey].

Makale geçmişi [Article Info]: Geliş Tarihi (Received): 18.12.2020. Kabul Ediliş Tarihi (Accepted): 14.01.2021.

İletişim [Correspondence]: Ramazan Gümral; Prof.Dr., Sağlık Bilimleri Üniversitesi, Gülhane Tıp Fakültesi, Tıbbi Mikrobiyoloji Anabilim Dalı, Ankara, Türkiye. E-posta: rgumral@gmail.com [Ramazan Gümral; Prof., Department of Medical Microbiology, Gulhane Medical Faculty, University of Health Sciences, Ankara, Turkey. E-mail: rgumral@gmail.com]
\end{abstract}

\section{Özet}

Messenger (haberci) ribonükleik asit (mRNA) moleküllerinin aşı veya genetik tedavi amaçı kullanımında protein ekspresyonunun etkinliğini belirleyen önemli parametrelerden biri bu moleküllerin hücre içerisine iletilmesinde başvurulan yaklaşımlardır. Viral vektör aracılı olmayan genetik bilgi transferi olarak da tanımlanan mRNA temelli aşı sistemlerinin hücrelere verimli bir şekilde iletilebilmesi için birçok farklı yaklaşım denenmiştir. Bu yöntemlerden biri mRNA moleküllerinin herhangi bir taşıyıcı molekül olmaksızın çıplak olarak dokulara doğrudan verilmesidir. Çıplak mRNA hücre dışı RNazlar (extracellular RNases) tarafından hızla yıkılır ve hücre içerisine verimli bir şekilde alınamaz. Bu nedenle, mRNA'nın hücreye alınmasını kolaylaştıran çeşitli biyokimyasal (protamin ve penetre edici peptitler gibi) ve fiziksel-mekanik yöntemler (elektroporasyon ve gen tabancası gibi) geliştirilmiştir. Öncelikle terapötik kanser aşılarının iletiminde başvurulan farklı bir yaklaşım ise otolog dendritik hücrelere (DH) ex-vivo mRNA yüklenmesi ve transfekte edilen DH'lerin tekrar dokulara enjekte edilmesidir. Ölçeklenebilir üretim için ideal bir yaklaşım olmayan bu sistem salgınlara müdahalede veya toplumsal bağışıklamada yetersiz kalacağı için bu stratejiye alternatif olan üçüncü bir mRNA iletim sistemi olarak nanopartikül taşıyıcılar geliştirilmiştir. Lipit nanopartiküller, polimerler ve katyonik nano-emülsiyonlar gibi farklı taşıyıcı sistemleri içeren bu nanopartiküller protamin, kolesterol ve polietilenglikol gibi çeşitli moleküllerin eklenmesi ile modifiye edilebilmektedir. Aşılama ile ulaşılmak istenilen hedefe göre mRNA temelli sistemler intradermal, subkutan, intranazal, intrasplenik, intravenöz ve intramusküler enjeksiyon gibi çeşitli yollarla doku-hedefli veya sistemik olarak verilebilmektedir. Bu derleme makalede mRNA bazlı aşıların hücrelere ve dokulara verimli bir şekilde in-vivo iletilmesi için kullanılan tekniklerin bir özeti sunulmuştur.

Anahtar Kelimeler: Optimizasyon, Lipit nanopartikül, Kararlılık, İmmünojenisite, RNaz.

\section{Abstract}

One of the important parameters determining the efficiency of protein expression in the use of messenger ribonucleic acid (mRNA) molecules for vaccine or genetic therapy is the approaches used in the delivery of these molecules into the cell. Many different approaches, also defined as non-viral vector-mediated gene transfer, have been tried in order to efficient delivery of mRNA-based vaccine systems to cells. One of these methods is delivery of naked mRNA molecules directly to tissues without any carrier molecules. Naked mRNA is rapidly degraded by extracellular RNases and cannot be efficiently taken into the cell. Therefore, various biochemical (such as protamine and penetrating peptides) and physical-mechanical methods (such as electroporation and gene gun) have been developed that facilitate the uptake of mRNA into the cell. A different approach, which is primarily used in the delivery of therapeutic cancer vaccines, is ex-vivo loading of mRNA 
into autologous dendritic cells (DCs) and re-injection of transfected DCs into tissues. Since this system, which is not an ideal approach for scalable production, will be inadequate in response to epidemics or in community immunization, nanoparticle carriers have been developed as a third mRNA delivery system as an alternative to this strategy. These carrier systems, include different designs such as lipid nanoparticles, polymers and cationic nano-emulsions, can be modified adding a variety of molecules such as protamine, cholesterol and polyethyleneglycol. mRNA based systems can be administered systemically or tissue-targeted by various means such as intradermal, subcutaneous, intranasal, intrasplenic, intramuscular and intravenous injections, depending on the target to be achieved by vaccinating. A summary of the techniques used for efficient in-vivo delivery of mRNA-based vaccines to cells and tissues was presented in this review article.

Keywords: Optimization, Lipid nanoparticle, Stability, Immunogenicity, RNase.

\section{Giriş}

Messenger (haberci) ribonükleik asit (mRNA) teknolojisi gen replasmanı, gen düzenlenmesi ve kanser immünoterapisi dahil olmak üzere çeşitli hastalıklar için yeni bir tedavi alternatifi olarak görülmektedir. mRNA temelli terapötik sistemlerin ve aşıların tedavi etkinliği ve ekspresyon verimliliği büyük ölçüde aşıda kullanılan in-vivo iletim sistemine bağlıdır. İletim sistemleri negatif yüklü büyük bir molekül olan mRNA yapılarını hücre içerisine taşımaya uygun hacimde ve genel olarak katyonik yüke sahip lipoprotein ve polimer yapılı nanopartiküller şeklinde tasarlanır [1]. Ekzojen mRNA, fonksiyonel proteine çevrileceği yer olan sitoplazmaya ulaşmak için lipit membran bariyerini geçmelidir [2]. mRNA için mevcut iletim stratejileri arasında çıplak RNA iletimi, polimerler, peptitler, emülsiyonlar ve lipit nanopartiküller (LNP) ve ayrıca kolaylaştırıcı fiziksel ve biyokimyasal yaklaşımlar bulunmaktadır [2-6]. Her bir stratejinin formülasyon kolaylığı, kararlılık, güvenlik, maliyet ve etkinlik açısından avantajları ve dezavantajları vardır. Amerikan Gıda ve İlaç Dairesi (U.S. Food and Drug Administration, FDA) tarafından onaylanan ilk RNA temelli tedavi olan küçük engelleyici RNA (siRNA) bazlı ilaç (Onpattro) sisteminde kanıtlandığı üzere, viral vektör aracılı olmayan RNA ilaç dağıtımı için en çok araştırılan ve klinik olarak güvenli teknoloji LNP'lerdir [1,7]. mRNA sitozole geçtiğinde, hücresel translasyon makinesi, ilgili proteini üretir ve bu protein hücre içerisinde post-translasyonel modifikasyonlarla uygun şekilde katlanmış ve tamamen işlevsel bir protein haline gelir. IVT (invitro-transcribed) mRNA normal fizyolojik süreçlerle bozulur ve böylece metabolit toksisitesi riski azalır ve ayrıca DNA sistemlerinde görülen kromozomal entegrasyon riski taşımaz [2].
Bugüne kadar tanıtılan mRNA aşılarının hücrelere iletimi için üç temel yaklaşım vardır. İlk yaklaşım mRNA'nın herhangi bir taşıyıcı olmadan doğrudan verilmesi (parenteral enjeksiyonu), ikincisi bir taşıyıcıyla birlikte verilmesi ve üçüncü olarak mRNA'nın otolog dendritik hücrelere (DH) ex-vivo yüklenmesi ve ardından transfekte edilmiş hücrelerin yeniden infüzyonu; mRNA aşılarında bu yöntemlerin birçok farklı modifikasyonları veya kombinasyonları denenmiştir $[2,4]$. mRNA iletim mekanizmaları hücre tipi ve mRNA komplekslerinin fizikokimyasal özellikleri ile de ilişkili olup, bu özellikler mRNA'ların hücresel iletimini ve organ dağııımını önemli derecede etkileyebilir [2]. mRNA aşıları intradermal, subkutan, intranodal, intrasplenik, intramusküler ve intravenöz enjeksiyon veya intranazal uygulama gibi farklı yollarla vücuda veya hedef dokulara verilebilen formülasyonlar şeklinde geliştirilmiş ve her bir yolun etkinliği ayrıca incelenmiştir [4].

\section{Doğrudan Çıplak mRNA ile Transfeksiyon}

Çıplak mRNA, in-vivo immünizasyonlar için, intradermal ve intranodal enjeksiyonlarda olduğu gibi özellikle antijen sunan hücreleri tercihli olarak hedefleyen aşı formatlarında kullanılmıştır [2]. Doğrudan mRNA enjeksiyonu nispeten hızlıdır ve maliyet etkindir, ancak bu konuda son zamanlarda önemli ilerlemeler kaydedilmiş olmasına rağmen, bu yaklaşım ile hücre tipine özgü ve verimli mRNA iletimi henüz tam olarak başarılmış değildir [2]. Tasarlanan mRNA molekülü uygulamadan sonraki erken dönemde dokularda ve kan dolaşımında bulunan RNazlar tarafından bozunmaya karşı dayanıklı olmalıdır. Ayrıca, mRNA'lar büyük ve polianyonik moleküller olduklarından, hücre zarı boyunca pasif olarak difüze olamazlar $[4,8]$, bu nedenle mRNA moleküllerinin hücre içine girişi 
endositik alım mekanizmaları aracılığıyla aktif taşınmaya dayanır. Bu durum, yapısı bozulmamış mRNA'nın antijen sunan hücreler (AntigenPresenting Cell, ASH veya APC) tarafından alınması durumunda bile, hemen hemen tüm mRNA moleküllerinin sonunda endo-lizozomal bölmede hapsolup bozunacağı anlamına gelir [4]. Replike olabilen mRNA'ların büyük boyutları ( 10 $\mathrm{kb}$, amplifiye olmayan mRNA ise 2-3 kb) nedeni ile bu sistemler antijen sunan hücreleri doğrudan transfekte etmede başarısız olabilir [4]. Tüm bu sorunları aşmak için farklı teknikler ve yaklaşımlar geliştirilmiştir. Çıplak mRNA ile elde edilen başarılara rağmen, mRNA aşılarının verilmesi için nanopartikül taşıyıcılarına yönelik araştırmalar daha yoğun bir şekilde devam etmektedir [4].
Kaplamasız (çıplak) mRNA

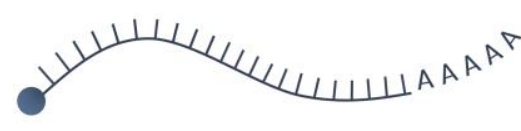

DH'lerin çıplak mRNA'yı çeşitli endositik yollar yoluyla içselleştirmesi

\section{Elektroporasyon}

Elektroporasyon işleminde yüksek voltajlı bir darbe ile hücre zarında gözenekler oluşturulur ve mRNA molekülleri buralardan geçerek sitoplazmaya girer.

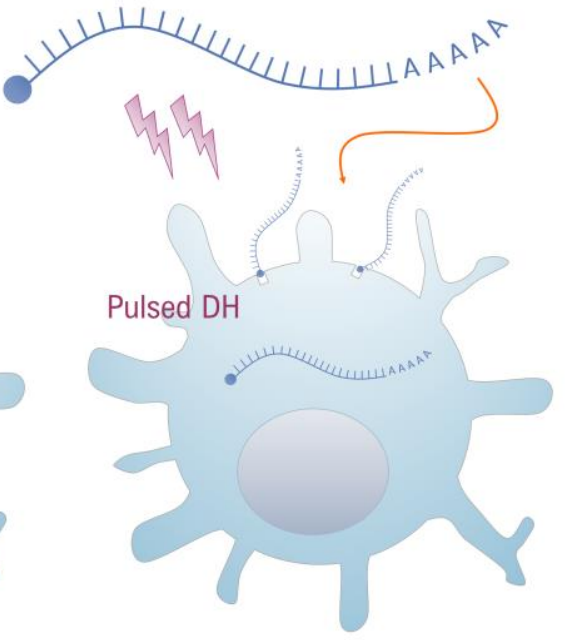

Protamin ile stabilize edilmiş çıplak mRNA

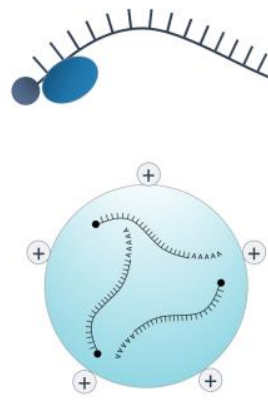

Katyonik nanoemülsiyon $100-130 \mathrm{~nm}$
Protamin lipozom
$(100 \mathrm{~nm})$ şeklinde de verilebilir
Ex-vivo mRNA yüklenmiş Dendritik hücreler

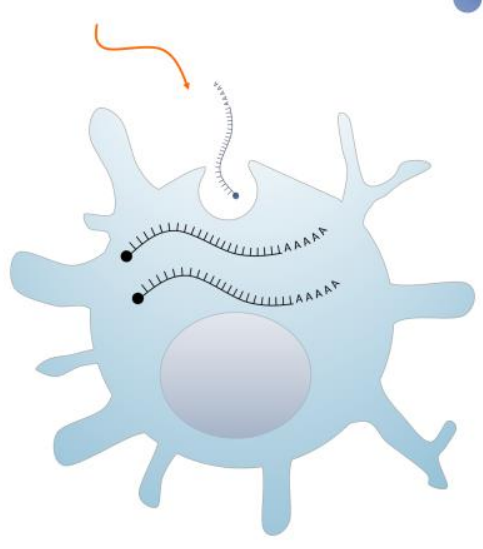

Şekil 1. mRNA'ların hücre içine iletimi için geliştirilen sistemler ve verilme yolları. Şekilde yer alan bazı görsellerin grafik tasarımında referans [2]'den yararlanılmıştır.

\section{Dendritik Hücrelere Ex-vivo mRNA Yükleme}

DH'ler, bağışıklık sisteminin en güçlü antijen sunan hücreleridir. Bu hücreler antijenleri içselleştirerek ve proteolitik süreçlerle işleyerek sırasıyla MHC sınıf I ve MHC sınıf II gibi temel doku uyumluluk kompleksleri (major histocompatibility complex, $\mathrm{MHC}$ ) üzerindeki $\mathrm{CD}^{+}$ve $\mathrm{CD}^{+}{ }^{+} \mathrm{T}$ hücrelere sunarak adaptif bağışıklık tepkisini başlatırlar. Ek olarak, DH'ler, antikor yanıtı uyarmak için B hücrelerine sağlam (intact) antijen sunumu da yapabilirler, bu hücreler mRNA transfeksiyonu için de oldukça uygun hücresel özelliklere sahiptir. Tüm bu nedenlerden dolayı, DH'ler hem ex-vivo hem de in-vivo mRNA aşı transfeksiyonu için ilgi çekici hedeflerdir [2]. DH'lere ex-vivo mRNA yükleme, hücresel hedefleme, transfeksiyon verimliliği ve diğer hücresel koşulların hassas kontrolüne izin verir [2]. DH'lerin çıplak mRNA'yı çeşitli endositik yollarla içselleştirebildiği gösterilmiş olmasına rağmen, transfeksiyon verimliliğini artırmak için genellikle elektroporasyon işlemine gereksinim duyulur; bu uygulamada yüksek voltajlı bir darbe (pulsing) ile hücre zarında gözenekler oluşturulur ve mRNA molekülleri veya farklı moleküller bu gözeneklerden geçerek doğrudan sitoplazmaya girer (Şekil 1). Bu mRNA iletim yaklaşımı bir taşıyıcı moleküle ihtiyaç duyulmadan yüksek transfeksiyon verimliliği üretme kabiliyeti nedeniyle tercih edilmektedir [9].

mRNA iletiminin etkinliğini değerlendiren ilk insan çalışmalarından biri (2002 yılı) otolog 
monositlerden türetilen DH'lerin prostat spesifik antijen kodlayan mRNA ile transfekte edildiği ve metastatik prostat kanseri olan hastalara bağışıklık tepkisini başlatmak üzere hücresel bağışıkığı uyaran bir aşı olarak yeniden verildiği bir ex-vivo yaklaşıma odaklanmıştır [10]. Ex-vivo mRNA yüklemeye dayalı DH aşılarının çoğu baskın olarak hücre aracılı bir bağışıklık tepkisi ortaya çıkarır; bu nedenle, bu aşılar öncelikle kanser tedavisinde kullanılmak üzere tasarlanmıştır [2]. Bununla beraber, yıllar geçtikçe bu yaklaşım, mRNA'nın LNP'ler aracılığı ile verilmesine doğru yönelmeye başlamıştır $[4,6]$. Çünkü hastaya özel DH'lerin izolasyonu ve kültürlenmesi maliyetli ve zahmetli bir süreç olduğu için bu uygulama hücresel bir tedavi biçimi olarak, aşılama için pahalı ve emek yoğun bir yaklaşımdır $[2,4]$.

\section{Fiziksel İletim Yolları}

mRNA moleküllerinin hücrelere alınmasını kolaylaştıran çeşitli biyokimyasal (protamin ve penetre edici peptitler ile modifiye etme) ve fiziksel-mekanik yöntemler (elektroporasyon ve gen tabancası gibi) geliştirilmiştir ve yine bu amaçla altın gibi bazı nanopartikül taşıyıcılar da denenmiştir [4-6].

\section{Elektroporasyon}

Elektroporasyon, hücre zarı bariyerini aşmak için kısa süreli yüksek voltaj darbelerinin kullanılmasını tanımlar. Hücre zarı kapasitansını aşan harici bir elektrik alanı uygulayarak, hücre membranının geçici ve tersine çevrilebilir (reversible) parçalanması indüklenebilir. Bu geçici geçirgenlik durumunda küçük moleküller basit difüzyon yoluyla yapısı bozulmuş zardan geçebilir ve bu şekilde elektroforetik süreçler yoluyla hücrelere yükleme yapılabilir. Başlangıçta gen transferi için geliştirilen elektroporasyon, şu anda iyonlardan ilaçlara, boyalara, antikorlara, oligonükleotidlere, deoksiribonükleik asit (DNA) ve RNA'ya kadar çok çeşitli moleküllerin hücre içine iletilmesi için kullanılmaktadır $[9,11]$.

\section{Gen tabancası}

İn-vivo mRNA alımının etkinliğini artırmada, hücre zarına nüfuz etmek için çeşitli fiziksel yöntemler de kullanılmıştır. Altın parçacıkları ile komplekslenen mRNA'nın bir mikroprojektil yöntemi olan bir gen tabancası kullanılarak dokularda eksprese edilebileceği gösterilmiştir [12]. Fare modellerinde gen tabancasının etkili bir RNA iletim yöntemi olduğu gösterilmiş olsa da, büyük hayvanlarda veya insanlarda etkinlik verisi mevcut değildir [2]. Artan hücre ölümü ve hedef hücrelere veya dokulara kısıtlı erişim nedeni ile fiziksel yöntemlerin kullanım alanı sınırlı kalmıştır. Son zamanlarda, bu alanın yerine güçlü ve çok yönlü uygulama araçları olarak lipit veya polimer yapılı nanopartiküllerin kullanılması tercih edilmektedir [2].

\section{Katyonik Peptitler}

Protamin, heparinin nötralizasyonu için ilaç olarak ve yavaş salınan insülin formülasyonlarında kullanılan doğal bir katyonik peptit karışımıdır. Ek olarak protamin, nükleik asitlerin (antisens RNA, siRNA, immünostimülatör nükleik asitler, plazmid DNA veya $\mathrm{mRNA}$ ) stabilizasyonu ve dağıtımı için kullanılabilir, bu nedenle de klinik geliştirme aşamasında olan birkaç farmakolojik bileşime dahil edilmiştir. Özellikle RNA ile karıştırıldığında protamin, formülasyon koşullarına (reaktiflerin konsantrasyonu, oranı ve tuzların varlığı) bağlı olarak 20-1000 nm boyut aralığında partiküller oluşturur ve bu partiküller aşılama ve immünostimülasyon için kullanılabilmektedir [13].

Bir polikatyonik peptit olan protaminin, mRNA'yı serum RNazları tarafından bozunmaya karşı koruduğu gösterilmiş olsa da, tek başına protamin ile komplekslenmiş bir mRNA'nın (muhtemelen protamin ve mRNA arasındaki sıkı birleşme nedeniyle) bazı kanser aşı modellerinde sınırlı protein ekspresyonu ve etkinliği sunduğu göstermiş̧ir [2]. Bu sorun, protaminle formüle edilmiş RNA'nın bir ekspresyon vektörü olarak tercih edilmesi yerine, TLR-7 aracılı immün yanıt aktivatörü olarak kullanıldığı RNActive aşı platformunun geliştirilmesiyle çözülmeye ve aşılmaya çalışılmıştır [14].

\section{Polimerler ve Lipit Nanopartiküller}

Güvenli ve etkili in-vivo mRNA iletimi için polimer ve lipit yapılı nanopartikül taşıyıcıların geliştirilmesinde büyük ilerlemeler kaydedilmiştir. Dendrimerler dahil olmak üzere katyonik lipitler ve polimerler, son yıllarda mRNA uygulaması için yaygın olarak kullanılan araçlar haline gelmiştir. mRNA alanı, on yıldan fazla bir süredir bu dağıtım 
araçlarının kullanıldığı in-vivo küçük müdahaleci RNA (siRNA) uygulamaları için yapılan önemli yatırımdan açıkça yararlanmıştır. Başlangıçta siRNA iletimi için geliştirilen iyonize edilebilir LNP'ler, günümüzde en ilgi çekici ve yaygın olarak kullanılan mRNA iletim araçlarından biri haline gelmiştir [3]. LNP'ler genellikle dört bileşenden oluşurlar; virüs boyutlu ( 100 nm) parçacıkların bir araya gelerek birleşmesini teşvik eden ve mRNA'nın endozomlar aracılığı ile sitoplazmaya salınmasına izin veren iyonize edilebilir bir katyonik lipit (DOTMA, DOTAP, D-Lin-MC3-DMA, C12-200); formülasyonların yarı ömrünü artıran lipit bağı polietilen glikol (DSPE-PEG, DMPE-PEG); stabilize edici bir ajan (kolesterol, DSPC, DPPC); ve çift katmanlı lipit yapıya destek olan doğal olarak oluşan fosfolipitler (Şekil 2) [1,2]. "Lipit
PEG ve antijen kodlayan-replike olabilen bir mRNA" ile formüle edilmiş ve dendrimerler olarak adlandırılan dallı poliamin bazlı polimerler tanımlanmıştır [3]. Dendrimer-RNA partikülleri ile yapılan immünizasyonun tek bir intramusküler dozda, antijene özgü CD8+ T hücresi ve farelerde Zika, Ebola ve influenza viruslara ve Toxoplasma gondii'ye karşı nötralize edici antikor yanıtları ortaya çıkardığı gösterilmiştir [3].

Bazı erken çalışmalar, klinik öncesi çalışma modellerinde mRNA aşı uygulaması için polietilenimin (PEI) gibi lipit olmayan polimerleri başarıyla kullanmış, ancak bu çalışmalar klinik aşamaya ulaşamamıştır [2]. mRNA iletimi için kullanılan polimerler, iletim materyalinin güvenlik profilini iyileştirmek için genellikle yağ asidi zincirleri ile modifiye edilmektedir [2].

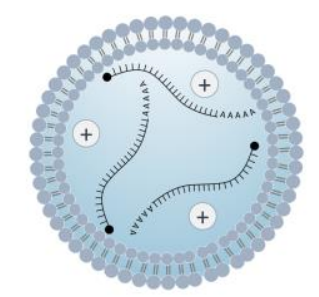

Katyonik polimer lipozom 100-200 nm

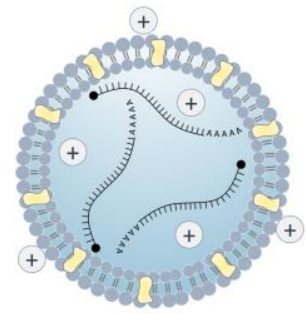

Katyonik lipit, kolesterol nanopartikül 80-200 nm

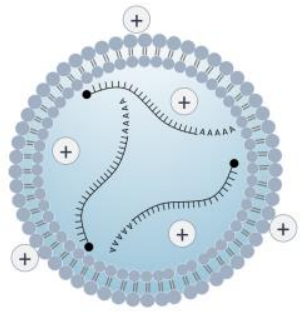

Katyonik lipit nanopartikül 80-200 nm

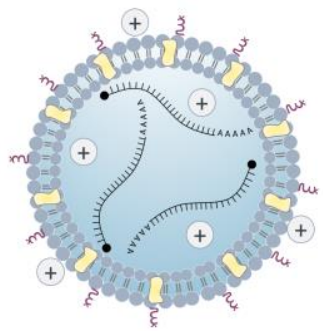

Katyonik lipit, kolesterol, PEG nanopartikül 80-200 nm

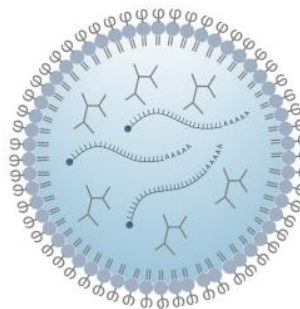

Modifiye dendrimer nanopartikül $200 \mathrm{~nm}$

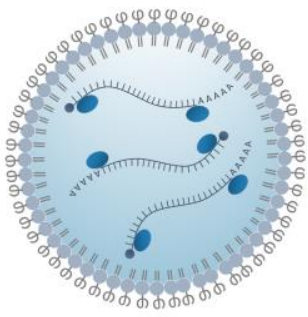

Protamin lipozom $100 \mathrm{~nm}$

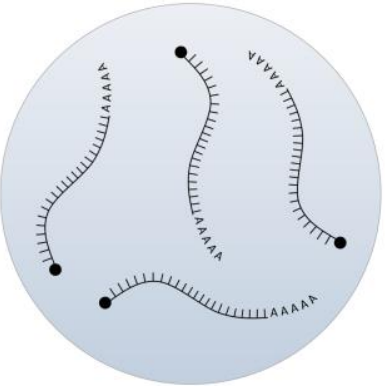

Polisakkarit nanopartikül $600 \mathrm{~nm}$

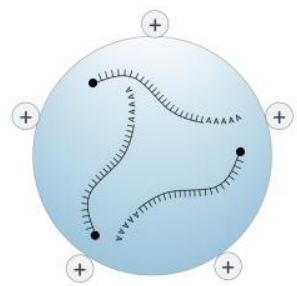

Katyonik polimer $100-300 \mathrm{~nm}$

Şekil 2. mRNA'ların hücre içine iletimi için geliştirilen polimer ve lipit temelli sistemler. Şekilde yer alan görsellerin grafik tasarımında referans [2]'den yararlanılmıştır.

Katyonik (pozitif yüklü) lipitler iletim sistemlerine genellikle negatif yüklü mRNA moleküllerinin elektrostatik kompleks oluşturması için dahil edilir. Bu lipitler basitçe amino grubunun pKa'sına göre $(\bullet)$ DOTMA, DOTAP ve DCkolesterol gibi "kalıcı olarak yüklü (permanentlycharged) lipitler" veya $(\bullet)$ D-Lin-MC3-DMA ve lipit benzeri molekül C12-200 gibi "pH'a bağlı iyonlaşabilir lipitler" olarak alt gruplara ayrılabilirler [4]. Orijinal olarak siRNA iletimi için optimize edilmiş olan ikinci grupta yer alan bu iyonize edilebilir lipitler fizyolojik pH koşulları altında nötr veya hafif katyonik yüke sahiptir. Bu durum, kalıcı olarak yüklü lipitlere göre belirli 
faydalar sunar, ki bu faydaların en önemlisi iyonlaşabilir lipitlerin azaltılmış toksisite ve uzun süreli kan dolaşımı ömrü ile ilişkilendirilmiş olmasıdır. Diğer lipit bileşenleri ise, $(\bullet)$ "yardımcı lipitler" olarak kabul edilirler. Yardımc lipitler mRNA LNP komplekslerinin yapısal düzenlemesini etkileyebilecek farklı fonksiyonel özellikleri ile bu komplekslerin stabilitesinin artırılmasında veya mRNA'nın (LNP halinde) hücre içi alımını ve sitozolik girişini teşvik ederler [4].

Genel transfeksiyon verimliliğini etkileyen anahtar engellerden biri de, hücre içerisine alınmış (engulfed) mRNA LNP'lerinin endozomal bozunmasıdır. Sonuç olarak, partiküle yüklenen mRNA moleküllerinin endozomlardan sitozole geçişini kolaylaştırmak için mRNA LNP'leri modifiye etmek ve optimize etmek için çok çaba harcanmaktadır. mRNA'nın endozomal salınımının arkasındaki temel mekanizmanın, LNP'lerin protonlanmış (iyonize) lipitleri ile endozomal membranın anyonik fosfolipitlerinin lipit karıştırma aşamasına (lipid-mixing step) bağlı olduğu öne sürülmüştür. Bu lipitler arasındaki iyon çifti oluşumunun, bir membran füzyonu oluşmasını ve membran destabilizasyonunu tetiklediği ve bunun da mRNA moleküllerinin endozomlardan kaçışını artırdığı düşünülmektedir [4]. Ek olarak, bu değişimin, LNP'leri ayrıştıracak ve endozomal membranın destabilizasyonunu destekleyebilecek iki katmanlı olmayan bir yapı dönüşümünü (yani lamellerden tersine çevrilmiş hekzagonal faza dönüşümü) indüklediği öne sürülmüştür. Sonuç olarak çalışmalar, mRNA ve lipit bileşenlerinin yapısal organizasyonunun elde edilebilecek nihai transfeksiyon verimliliği ile ilişkili olduğunu göstermiştir. Membran füzyonu teorisi on yıldan fazla bir süredir var olmasına rağmen, LNP'lerin mRNA'nın sitozolik dağıtımını teşvik etme mekanizmasının yalnızca bu tek özelliğe indirgenemeyeceği belirtilmektedir [4]. Daha yeni çalışmalar, mRNA LNP'lerinin endositik trafiğinin, mRNA'nın sitozolik girişini ve translasyonunu etkileyen geri dönüşüm yollarını ve sinyal yollarını içeren dinamik bir süreç olduğunu açıklamaktadır [4].

Yakın zamanda, T hücrelerini etkin bir şekilde hedefleyen ve farelerde lokal tümörlerin temizlenmesine yol açan, yük değiştiren taşıyıcılar (charge-altering releasable transporters, CART) adı verilen yeni bir lipit içeren polimer grubu geliştirilmiştir [3]. T hücrelerinin manipülasyonu zordur ve sıklıkla ex-vivo işlemler gerektirir (donörlerden elde edilen $\mathrm{T}$ hücrelerinin saflaştırılması, nükleik asit ile elektroporasyon, çoğaltma ve yeniden infüzyon gibi); bu nedenle CART'lar, mRNA aşıları ve gen terapisi alanlarında büyük potansiyele sahip çok çekici iletim materyalleri olarak görülmektedir [3]. Tüm mRNA iletim sistemlerinden farklı olarak, CART sisteminin temel bir özelliği, başlangıçtaki polikatyonik CART molekülünü nötr yan ürünlere dönüştüren bozunma mekanizmasıdır, böylece taşınan polianyonik mRNA'nın endozomal kaçışı, salınımı (release) ve ardından translasyonu mümkün olmaktadır [8]. Yeni bir transfeksiyon sınıfını temsil eden CART taşıyıcılar iyi tolere edilen küçük nötr moleküllere indirgendiğinden dolayı, bu moleküllerin kullanımı durumunda katyonik lipitler ve diğer katyonik materyallerle ilişkili "bilinen doza bağımlı toksisite" endişeleri ortadan kaldırılmış olur [8].

Nanopartikül taşıyıcı sistemler ex-vivo DH transfeksiyon stratejisi ile kombine olarak da kullanılabilmektedir. Kranz ve ark. [15], sistemik uygulamadan sonra DH'leri tercihli olarak hedefleyen lipopleksler üzerinde çalışmıştır. Güçlü immün yanıtları indüklemek için mRNA aşıları ile seçici DH hedeflemesi, potansiyel olarak kritik bir keşiftir ve bu platform, klinik çalışmalarda umut vaat etmiştir ve kişiselleştirilmiş kanser aşıları bağlamında aktif olarak araştırımıştır [3].

Hücre penetre edici peptitler (cell-penetrating peptides, CPP) mRNA aşıları için nadiren kullanılır, ancak bu alanda son zamanlarda bazı ilerlemeler kaydedilmiştir [3]. Udhayakumar ve ark. [16], mRNA'yı "membranları bozan ve hücre içerisine nüfuz edebilen partiküller ve kompleksler" halinde yoğunlaştırmak için amfipatik Arg-Ala-Leu-Ala motifleri içeren CPP'ler geliştirdiler ve fareleri CPPkompleksli mRNA ile bağışıkladıktan sonra güçlü sitolitik $T$ hücre yanıtları elde ettiler. Bu platformun güçlü antikor tepkilerini uyarıp enfeksiyonlara karşı koruyucu immün yanıtı indükleme düzeyinin gelecekteki çalışmalar ile ortaya konması beklenmektedir [3].

TransIT-mRNA (Mirus Bio LLC) gibi katyonik polimer-lipit formülasyonları veya Lipofectamine 
(Invitrogen) gibi lipozom oluşturan katyonik lipit formülasyonlarına dayanan ticari yüksek verimli mRNA transfeksiyon reaktifleri de mevcuttur [2]. Bu sistemler birçok primer hücre dizisi ve kanser hücre dizilerinde etkin bir şekilde çalışmakla beraber, sınırlı in-vivo etkinlik ve toksisite riskleri olduğuna dair gözlemler de bulunmaktadır [2].
Çıplak RNA moleküllerinin "kısa yarı ömürleri, zayıf stabiliteleri ve nükleazlar tarafından kolay parçalanmaları" gibi in-vivo iletimin zorluklarını aşmak için geliştirilen nanopartikül bazlı sistemlerin her birinin; biyolojik uyumluluk, stabilite ve toksisite riski gibi farklı avantaj ve dezavantajları vardır (Tablo 1) [5].

Tablo 1. Hücresel RNA iletimi için nanopartikül tabanlı platformların avantaj ve dezavantajları $[5,6]$.

\begin{tabular}{|c|c|c|c|}
\hline $\begin{array}{l}\text { Nanopartikül } \\
\text { taşıyıcı }\end{array}$ & Örnek sistemler & Avantajlar & Dezavantajlar \\
\hline $\begin{array}{l}\text { Lipit bazlı nano } \\
\text { materyaller }\end{array}$ & $\begin{array}{l}\text { o Lipozomlar } \\
\text { o Katı lipit nanopartiküller } \\
\text { o Lipit emülsiyonları } \\
\text { * Pozitif yüklü lipozomlar } \\
\text { nükleotidlerle nanopartikül veya } \\
\text { kompleksler oluşturmak üzere } \\
\text { iyonik olarak etkileşirler. }\end{array}$ & $\begin{array}{l}\text { - Kolay hazırlanma } \\
\text { o Biyo uyumluluk } \\
\text { o Biyolojik parçalanabilirlik } \\
\text { o Yük nötralizasyonu ve büyüklükleri } \\
\text { ASH tarafından alınmaya uygundur } \\
\text { - Lipozomlar ve lipit kompleksler FDA } \\
\text { tarafından uzun yıllardır onaylanmış } \\
\text { durumdadır } \\
\text { o siRNA temelli bir lipit taşıyıcı sistem } \\
\text { FDA tarafından onaylanmıştır }\end{array}$ & $\begin{array}{l}\text { o Sınırlı stabilite, sıklıkla çok } \\
\text { düşük soğuk saklama } \\
\text { koşullarına gereksinim } \\
\text { o Yüklenen materyali kolay } \\
\text { sızdırma } \\
\text { o Hızlı klerens (temizlenme) } \\
\text { o Polietilenglikol ve } \\
\text { fosforilkoline önceden } \\
\text { immünite gelişmiş olabilir } \\
\text { veya aşılama ile } \\
\text { indüklenebilir }\end{array}$ \\
\hline $\begin{array}{l}\text { Polimer bazlı } \\
\text { nano } \\
\text { materyaller }\end{array}$ & $\begin{array}{l}\text { o Doğal veya doğal yoldan } \\
\text { türetilmiş polimerler (kitosan, } \\
\text { poli-I-lisin, atelocollagen vb.) } \\
\text { o Sentetik polimerler (PLGA, PEI, } \\
\text { PVA, PLA, PEG gibi). } \\
\text { * Pozitif yüklü polimerler } \\
\text { nükleotidlerle nanopartikül } \\
\text { kompleksleri oluşturmak üzere } \\
\text { iyonik olarak etkileşirler. }\end{array}$ & $\begin{array}{l}\text { - Doğal veya doğal olarak türetilmiş } \\
\text { polimerler için biyo-uyumluluk } \\
\text { o Biyolojik olarak parçalanabilirlik } \\
\text { o Düşük üretim maliyeti } \\
\text { o İlaç salınımının uyarılması } \\
\text { o Kolay modifikasyon } \\
\text { o Bazı polipleksler topikal } \\
\text { uygulamalar için FDA onayı almıştır } \\
\text { o Yük nötralizasyonu ve büyüklükleri } \\
\text { ASH tarafından alınmaya uygundur } \\
\text { o Nükleotidler polimerler tarafından } \\
\text { kısmen veya tam olarak korunur }\end{array}$ & $\begin{array}{l}\text { - Bazı polimerler bozunmaz } \\
\text { (nondegradable) } \\
\text { - Doza bağlı toksisite riski söz } \\
\text { konusu olabilir } \\
\text { - Katyonik polimerler konak } \\
\text { DNA'ya da bağlanabilir ve bu } \\
\text { durum toksisite endişesine } \\
\text { neden olur }\end{array}$ \\
\hline $\begin{array}{l}\text { İnorganik } \\
\text { nanopartiküller }\end{array}$ & $\begin{array}{l}\text { o Metal nanopartiküller (örneğin, } \\
\text { demir oksit ve altın } \\
\text { nanopartiküller) }\end{array}$ & $\begin{array}{l}\text { o Kolay yüzey modifikasyonu } \\
\text { o Tekrarlanabilirlik } \\
\text { o Kolay hücre alımı }\end{array}$ & $\begin{array}{l}\text { - Biyolojik olarak bozunmazlık } \\
\text { (non-biodegradability) } \\
\text { o Potansiyel toksisite }\end{array}$ \\
\hline $\begin{array}{l}\text { Biyoesinlenmiş } \\
\text { nano araçlar }\end{array}$ & $\begin{array}{l}\text { o DNA temelli nano yapılar } \\
\text { o Ekzozom-benzeri nano veziküller } \\
\text { o Eritrosit temelli hayalet } \\
\text { taşıyıcılar (nanoerythrosomes) }\end{array}$ & $\begin{array}{l}\text { o İyi biyolojik bozunabilirlik } \\
\text { o Düşük toksisite } \\
\text { o Güçlü hedefleme ve düşük bağışıklık } \\
\text { indüksiyonu }\end{array}$ & $\begin{array}{l}\text { ○ Yüksek maliyet } \\
\text { o Stabilite endişesi }\end{array}$ \\
\hline
\end{tabular}

\section{mRNA Așılarının Uygulama Bölgelerì}

mRNA aşılarının uygulama yolu ve dağıtım (delivery) formatı, tedavide hedeflenen sonuçları önemli ölçüde etkilemektedir. Öyle ki, mRNA-LNP aşılarının in-vivo protein üretiminin düzeyi ve süresi, uygulama yolunu değiştirerek kısmen kontrol edilebilmektedir. mRNA aşıları için yaygın uygulama yolları (intradermal, intramusküler, subkutanöz veya intranazal) yanında bazı alışılmadık aşılama yollarının (intranodal, intravenöz, intrasplenik veya intratümöral) da test edildiği çeşitli mRNA aşı formatları geliştirilmiştir (Şekil 3) [2]. Sistemik olarak verilen mRNA-LNP kompleksleri, apolipoprotein E'nin bağlanması ve hepatositler tarafından reseptör aracılı alım nedeniyle esas olarak karaciğeri hedef alır, bu nedenle bu uygulama yolu çok tercih edilen bir yaklaşım değildir [2]. mRNA-LNP'lerin intradermal, subkutan ve intramusküler yolla verilmesinin sistemik uygulamaya kıyasla daha kalıcı protein ekspresyonuna neden olduğu gösterilmiştir [2].

ASH'lerin T hücrelere çok yakın olduğu lenfoid organlar, T hücre yanıtlarının verimli bir şekilde 
uyarılması için ideal mikro ortamlar olarak değerlendirilmiş ve lenf nodları spesifik aşı uygulama bölgeleri olarak seçilmiştir [15]. Yine deride çeşitli $\mathrm{ASH}^{\prime}$ ler bulunmakta ve bu da deri dokusunu aşılama sırasında immünojenlerin verilmesi için ideal bir yer haline getirmektedir. Bu nedenle intradermal uygulama mRNA kanser aşıları için yaygın olarak kullanılmaktadır [2]. Erken bir çalışmada (2000), toplam tümör RNA'sının ex-vivo yüklendiği hücrelerin intradermal uygulanmasının tümör büyümesini geciktirdiği gösterilmiştir [17]. Protamin bazlı
RNActive platformunda tümör antijenlerini kodlayan mRNA'nın intradermal enjeksiyonu ile çeşitli fare kanser modellerinde ve çok sayıda profilaktik ve terapötik klinik ortamda etkili olduğu kanıtlanmıştır [2]. Lipit bazlı taşıyıcılar intradermal olarak verilen mRNA kanser aşılarının etkinliğine de katkıda bulunmuştur [2]. Antiviral aşılar ise subkutan yol ile verilebilmekle beraber, SARS-CoV-2 için acil kullanım onayı alan aşılarda (BNT162b2 ve mRNA-1273) olduğu gibi koruyucu mRNA aşıları için daha çok intramusküler yol tercih edilmektedir [18-20].

\section{Nanopartiküller}

mRNA moleküllerinin hücre içine iletimini kolaylaştırmak için kullanılan koruyucu sistemlerdir. Güvenlikle ilgili ek değerlendirmeler

ve maliyet artışı önemli konulardır.

Intravenöz: Kan komponentleri ile etkileşim, opsonizasyon ve fagositik hücreler tarafından klerens. Nanopartiküllerin boyutları ve yükü dolaşımda kalma süresini ve karaciğer, dalak ve akciğerler gibi organlara dağılımını etkiler.

Lenfatik transport: mRNA nanopartiküllerinin kenfatik sistemde pasif transportu. Hücre dışı matrikste etkin bir şekilde taşınabilmesi için partikül boyutu $<200 \mathrm{~nm}$ olmalıdır.

\section{Çıplak mRNA}

Üretilmesi kolay olup hedef bölgeye lokal olarak uygulanırlar. İn-vivo olarak hızlı yıkıırlar.

Deri yolu: intramusküler, inrtadermal ve subkutan yollar. Derideki ASH'ler ve somatik hücreler hedeflenir. Matür hücreler lenf nodlarına göç ederler.

İntratümoral: Tümör dokusundaki ASH tarafından alınır.

Intranodal: Lenf nodlarında bulunan makrofajlar ve ASH'ler hedeflenir. mRNA'lar makropinositozla hücre içine alınır. Ultrasonografi rehberliğinde enjeksiyon yapilır.

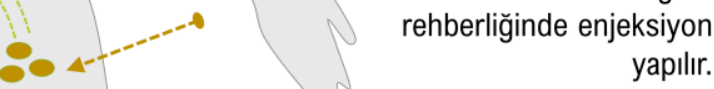

Ołolog Dendritik Hücreler Daha çok terapötik kanser aşılarının verilmesinde tercih edilir.

Şekil 3. mRNA aşılarının in-vivo verilme yolları. Şekildeki bazı bilgiler referans [4]'den alınmıştır.

\section{Sonuç}

Terapötik aşılarda mRNA iletiminin kritik rolü nedeniyle, daha geniş klinik uygulama için güvenli, etkili ve ayarlanabilir mRNA iletim araçlarının kullanıma sunulması ve etkinlik ve toksisite durumlarının detaylı bir şekilde değerlendirilmesi gerekmektedir. Her ne kadar bazı mRNA molekülleri (özellikle replike olabilen tasarımlar) büyük moleküller olsa da, farklı ilaçlar ve daha küçük moleküllerin in-vivo iletimi için tasarlanan ve geliştirilen platformlar aynı zamanda mRNA iletim platformları olarak mRNA aşılarına da hızla adapte edilebilmektedir. Geleceğin önemli teknolojilerinden biri olarak görülen mRNA temelli terapötik sistemler için özellikle küresel boyutta devam eden SARS-CoV2 aşılama programlarından elde edilen sonuçlar güvenlik, etkinlik, ölçeklenebilir üretim ve maliyet değerlendirmeleri hakkında da değerli bilgiler sunacak ve önemli tecrübeler kazandıracaktır.

Çıkar beyanı: Yazar çıkar çatışması bildirmemiştir. Makalenin içeriğinden ve yazılmasından tek başına yazar sorumludur. Finansal destek: Bu çalışmaya finansal destek verilmemiştir. 


\section{Kaynaklar}

1. Blakney AK, Deletic $P$, McKay PF, Bouton CR, Ashford $M$, Shattock RJ, et al. Effect of complexing lipids on cellular uptake and expression of messenger RNA in human skin explants. J Control Release 2020: S01683659(20)30683-0. [Epub ahead of print] [Crossref]

2. Pardi N, Hogan MJ, Porter FW, Weissman D. mRNA vaccines - a new era in vaccinology. Nat Rev Drug Discov 2018; 17(4): 261-79. [Crossref]

3. Pardi N, Hogan MJ, Weissman D. Recent advances in mRNA vaccine technology. Curr Opin Immunol 2020; 65: 14-20. [Crossref]

4. Verbeke R, Lentacker I, De Smedt SC, Dewitte H. Three decades of messenger RNA vaccine development. Nano Today 2019; 28: 100766. [Crossref]

5. Lin $Y X$, Wang $Y$, Blake $S$, Yu M, Mei $L$, Wang $H$, et al. RNA Nanotechnology-Mediated Cancer Immunotherapy. Theranostics 2020; 10(1): 281-99. [Crossref]

6. Batty CJ, Heise MT, Bachelder EM, Ainslie KM. Vaccine formulations in clinical development for the prevention of severe acute respiratory syndrome coronavirus 2 infection. Adv Drug Deliv Rev 2020; 169: 168-89. [Crossref]

7. US Food and Drug Administration (FDA), Silver Spring, Maryland, USA. Proprietary name: Onpattro ${ }^{\mathrm{TM}}$ (patisiran). Center For Drug Evaluation and Research Application Number: 210922Orig1s000. 2018. Available at:

https://www.accessdata.fda.gov/drugsatfda_docs/nda/ 2018/210922Orig1s000MultiR.pdf [Accessed December 29, 2020].

8. Haabeth OAW, Blake TR, McKinlay CJ, Waymouth RM, Wender PA, Levy R. mRNA vaccination with chargealtering releasable transporters elicits human $T$ cell responses and cures established tumors in mice. Proc Natl Acad Sci U S A 2018; 115(39): E9153-E9161. [Crossref]

9. Gu $Y Z$, Zhao X, Song XR. Ex vivo pulsed dendritic cell vaccination against cancer. Acta Pharmacol Sin 2020; 41(7): 959-69. [Crossref].

10. Heiser A, Coleman D, Dannull J, Yancey D, Maurice $M A$, Lallas $C D$, et al. Autologous dendritic cells transfected with prostate-specific antigen RNA stimulate CTL responses against metastatic prostate tumors. J Clin Invest 2002; 109(3): 409-17. [Crossref]
11. Gehl J. Electroporation: theory and methods, perspectives for drug delivery, gene therapy and research. Acta Physiol Scand 2003; 177(4): 437-47. [Crossref]

12. Qiu $P$, Ziegelhoffer $P$, Sun J, Yang NS. Gene gun delivery of mRNA in situ results in efficient transgene expression and genetic immunization. Gene Ther 1996; 3(3): 262-8.

13. Jarzebska NT, Lauchli $S$, Iselin $C$, French $L E$, Johansen P, Guenova E, et al. Functional differences between protamine preparations for the transfection of mRNA. Drug Deliv 2020; 27(1): 1231-5. [Crossref]

14. Kallen $K J$, Heidenreich $R$, Schnee $M$, Petsch $B$, Schlake $T$, Thess $A$, et al. A novel, disruptive vaccination technology: self-adjuvanted RNActive $(\circledR)$ vaccines. Hum Vaccin Immunother 2013; 9(10): 2263-76. [Crossref]

15. Kranz LM, Diken $M$, Haas $H$, Kreiter $S$, Loquai $C$, Reuter KC, et al. Systemic RNA delivery to dendritic cells exploits antiviral defence for cancer immunotherapy. Nature 2016; 534(7607): 396-401. [Crossref]

16. Udhayakumar VK, De Beuckelaer A, McCaffrey J, McCrudden CM, Kirschman JL, Vanover D, et al. Arginine-Rich Peptide-Based mRNA Nanocomplexes Efficiently Instigate Cytotoxic $T$ Cell Immunity Dependent on the Amphipathic Organization of the Peptide. Adv Healthc Mater 2017; 6(13). [Crossref]

17. Granstein RD, Ding W, Ozawa H. Induction of antitumor immunity with epidermal cells pulsed with tumorderived RNA or intradermal administration of RNA. J Invest Dermatol 2000; 114(4): 632-6. [Crossref]

18. Ulmer JB, Geall AJ. Recent innovations in mRNA vaccines. Curr Opin Immunol 2016; 41: 18-22. [Crossref]

19. Polack FP, Thomas SJ, Kitchin N, Absalon J, Gurtman A, Lockhart S, et al.; C4591001 Clinical Trial Group. Safety and Efficacy of the BNT162b2 mRNA Covid-19 Vaccine. N Engl J Med 2020; NEJMoa2034577. [Crossref]

20. Baden LR, El Sahly HM, Essink B, Kotloff K, Frey $S$, Novak R, et al.; COVE Study Group. Efficacy and Safety of the mRNA-1273 SARS-CoV-2 Vaccine. N Engl J Med 2020; [Online ahead of print]. [Crossref] 